\title{
Evaluation of Corporate Strategy and Dynamic Capability to Business Performance
}

\author{
Roy Kurniawan $^{1}$, Budiman Christiananta ${ }^{2}$, Lena Ellitan ${ }^{3}$ \\ rykurniawan.com \\ ${ }^{1,2,3}$ Universitas Katolik Widya Mandala Surabaya, School of Post Graduate, \\ Surabaya, Indonesia
}

\begin{abstract}
:
A dynamic business environment can affect a company's business sustainability. This condition will create a competition that must be faced by the business. On the basis of this, the business must be able to apply the right company strategy to realize the dynamic capabilities so that will be able to survive in the global competition and achieve the expected performance. This paper will examine the concepts of strategies undertaken by businesses on the realization of dynamic capabilities and improve overall business performance.
\end{abstract}

Keywords: Synergy Cooperation, Business Performance, Supplier Network Strategy, Business Development Strategy.

\section{Introduction}

Changes that occur in the business environment dynamically can affect the sustainability of a company's business. Under these conditions, competition is crucial to the success or failure of a company's business. Competition in the business world lately is also increasingly tight with many competitors who offer similar products with affordable price and quality so chosen by consumers, not least with companies located in Indonesia [1]. Conditions will be increasingly complex with the challenges that will be faced is the opening of boundaries and limits of competition, so that economic activity will depend on free global competition open and in the end only a strong businessman who will win and stay afloat [2]. Under these conditions, it is very important for companies to be able to implement appropriate and effective business strategies to be able to compete with other companies to achieve better corporate performance.

Companies must be able to run a brilliant competitive strategy so that it has advantages compared with its competitors for the sustainability of its business. Competitive strategy is an attempt to find a competitive position in a profitable industry, because this is very fundamental for the company when the competition is in progress. Thus it can be argued also that companies that are able to survive in the competition is a company that can adjust itself to changes that occur in the business world whether it changes in the consumer or even companies associated with technology [1].

Business performance is the key to staying survive in a global era. Even companies in Indonesia consider the competition in the global era and digital economy as a challenge that must be achieved and made an opportunity to support national economic growth. In addition, another reason is the development of technology is something that we cannot avoid, so the development of technology should be able to address the company wisely so as to improve and utilize evolving technologies to evaluate and run its business [3].

Factors that can be put forward by the company in order to make changes in order to face the level of business competition is increasingly strong include improvements in supplier network strategy, cooperation synergies with other companies, dynamic capabilities of the company itself, business development strategy so that ultimately can improve the overall performance of the company. Synergy means cooperation between companies within the same industry group. Synergy will create creative partnerships for competitive strategies that are useful 
in realizing dynamic capabilities [4]. On the other hand, a business development strategy that is part of the business strategy needs to be done to reconfigure the company's resources to be able to provide innovative, adaptive and flexible capabilities as internal strengths that become antecedents of dynamic capabilities [5]. Furthermore, with the strategy on the supplier network will be known management the entire inventory flow of suppliers' right down to the end customer. The orientation of this strategy will be able to give birth to cooperation efforts perform synchronization and interconvergence company and inter-company operations as well strategic capability into a unified whole intact and focus on creating uniqueness of value customers [6].

However, the problems that often occur are in the implementation of strategies that have been designed sometimes still cannot be implemented well by the company in the field, so that the coveted improvements have not been in line with expectations. Thus, the management or management of the company must be able to integrate all aspects and resources owned by the company in order to synergize with both within the company's own environment or synergize with the environment outside the company is doing cooperation with other companies or suppliers that can help the creation of operationalization companies that are effective and capable of producing maximum and acceptable products of the market [3].

Based on this, it will be studied deeply the link between corporate strategy in terms of cooperation synergy, business development strategy, supplier network strategy and dynamic capabilities in an effort to achieve good business performance..

\section{Literature Review}

\subsection{Strategic Management and Resource-Based View (RBV)}

The research is a research in the field of strategic management that focuses more on the perspective of resource based view on a company. Strategic management is a group of managerial decisions and actions that can determine the organization's longterm performance [7]. Meanwhile, the connection with resource based view is a strategic management conception that puts pressure on the importance of company's resources and capabilities which, when managed properly, will result in the ability to produce above normal return rates and therefore can be a strategic instrument to produce sustainable competitive advantage Sustainable Competitive Advantage (SCA) [8].

Barney [8] focuses on assets and skills, or assets and competencies as the most basic strategic instrument to produce a foundation for sustainable competitiveness. Resource Based View states that corporate earnings can be above normal if they have much better resources and they are protected by a kind of isolation mechanism preventing their spread [9].

RBV discusses the company's internal resources and capabilities as well as its relationship to strategic decision making. In addition, RBV explains how corporate resources affect externally competitive outcomes and processes. The addition of RBV is a factor of corporate competition and the role of internal resources to the firm in determining competitive outcomes [10]. In addition, the concept of RBV also gives more attention to organizational learning, accumulation in knowledge, development abilities, and the process of changing associations between companies. Thus the dynamics present in RBV's theory pay attention to the relationship of those things [11].

\subsection{Cooperation Synergy}

Cooperation is a social capital (Social Capital) within an organization. The ability to build cooperative relationships is a strategic asset for the organization, as more partnerships will strengthen partnerships, inter-organizational collaboration, the growing number and breadth of business networks, making it difficult to imitate competitors because it requires organizational learning. Meanwhile, another definition of cooperation within an organization means working together to achieve common goals, is the process of working together with others to always achieve better than agreed or set goals [12].

Synergy is a condition of cooperation between two or more parties that influence each other, where the effect of cooperation is much greater than if they do it individually [13]. Synergy can also be interpreted as the overall result achieved greater than the result of the number of parts (individuals) that work together [14].

Based on the meanings outlined above, it can be understood that cooperation will result in synergy when greater results are obtained, dynamic action combinations, and individually they are not able to predict the overall behavioral system, but with the 
synergy of cooperation will be more accurate in understanding the behavior unexpected.

The synergy of cooperation in inter-organizational relations is derived from the results of the relational exchanges between the parties working together in the form of complementary cooperation, subsitution or buyer-seller transactions, as well as the use of shared assets [13].

The synergies of cooperation in business are also grouped into: Horizontal Synergy, Vertical Synergy and Triangle Synergy [15]. Horizontal synergies are synergies made by businesspeople working together in the same market or competing for the same market. Vertical synergy is a synergy that is done by business actors whose functions are complementary (complementary). While the synergy of triangle is the synergy done by many parties: between competitor, complementary and other organizations with an interest in the cooperation.

\subsection{Supply Network Strategy}

Supply network strategy is a new concept of management and supply chain management philosophy that was born as the solution of decision makers in the face of increasingly complex problems. In the line of operations and firmly rooted in the company's supplier performance, the existence of Supply network strategy is focused on the problem of supplier performance development through a network of suppliers (supply network). Further Supply network strategy is positioned as a "planning" (planning) approach in a management strategy. This assumption arises because of the enormous benefits and significance of a company with regard to its operations to better understand and develop the role of network management.

Supply network strategy focuses on three important things, namely trust in cooperation, communication in cooperation and changes in environmental dynamics that occur [16].

Trust in a partnership can be explained as being where a party has a trust in a trustworthy and integrity partner. Trust in cooperation is also defined as the desire to trust a credible partner [17]. Trust in cooperation contains two important components: 1) credibility based on the extent to which retailers believe that suppliers have the skills necessary to perform the job effectively and relibally and 2) benevolence based on the extent to which retailers believe that the supplier has a favorable motive and motive for retailers when new conditions arise. [18].
The concept of trust in cooperation between retailers in suppliers affects long-term orientation on the perceived reasons: 1) can reduce perceptions of risks associated with the possibility of opportunistic behavior by suppliers, 2) increase confidence in retailers that short-term inequities will be solved in long periods, 3) can reduce transaction costs in exchange relations [18].

Communication in cooperation can be explained as a communication of supplier networks that can foster development by helping to resolve the perceptions of disputes and disputes and meet the expectations of both parties working together. Communication in co-operation can also be described as a glue that unifies channel performance of supplier networks [17].

Environmental dynamics are the degree of uncertainty that companies face to guide management to scanning environmental factors as well as factors that are environmental threats, as measured by a) firms respond to strategies implemented by competitors, b) companies respond to substitution product types more and more.

\subsection{Business Development Strategy}

Development strategy is the ways that companies do in order to develop the business and business run. Business development strategy in concept can be done with several methods, namely: [19]

\section{Market Penetration}

Market penetration is done by selling large quantities of old products to the old market in other words if production is increased in quantity the product is still acceptable and absorbed by the existing market. Market penetration strategy is a development strategy that has the highest risk because it utilizes many resources and capabilities of the company. Theoretically, in a growing market, simply maintaining market share will result in growth, but keep in mind that market penetration is a limit and once a market approach is saturated then other strategies must be pursued if the company wants to continue to grow.

\section{Market Expansion}

This market expansion means having to find new markets for the same type of product. This expansion is an attempt to market the excess of production that is not absorbed by the old market or intentionally done to increase the level of product 
sales. New market expansion strategy can be a better business development strategy if the basic competence of the company is more related to a particular product than its experience with a particular market segment.

\section{Product Development}

Product development strategy will concern the market and product directly and if the existing market situation is possible for new product then product development strategy can be implemented. Product development strategy will be successful if the strength of the company associated with a particular customer rather than a particular product itself. This strategy is done by taking into account the exact timing and strategy carried out in introducing the new product, so the introduction of the new product is related to the strength of the company.

\section{Product Differentiation}

Performing several innovations to the product is the intention of product differentiation that is with the development or innovation of existing products. To create consumer satisfaction, marketers can differentiate and generate more sales than do not differentiate, but differentiation can increase company costs.

\section{National and International Business Expansion}

National level expansion is easier to do than international level. Information that is easy to obtain, risks faced and opportunities can be assessed carefully and thoroughly, thus large expansions will require large and often unfavorable costs. To penetrate the market abroad is not easy and the conditions are also not simple. There should be a high quality stability and this strategy will change from the size of the company itself so that it will cause changes to the company's operations. In addition, the financial structure will add to the attractiveness of the international expansion plan for investors and consumers who are abroad.

\subsection{Dynamic Capabilities}

Dynamic capability is defined as the company's ability to integrate, build, configure internal and external competencies in the face of environmental change [20]. Another definition mentioned that dynamic capabilities in the context of creating capabilities without waiting for a crisis from the external environment, where dynamic capabilities are procedures and routine organizational activities that occur in an effort to integrate, reconfigure, obtain or even release the company's resources to improve company performance and achieve corporate goals [21].

Dynamic capability is the capacity to extract current resource capabilities into future resource capabilities through the development of new competencies, the dynamic capabilities will include two elements, (1) capability to exploit capabilities and (2) the capability to build new things ( capability building) [22].

Dynamic capabilities appear as an extension of RBV, where RBV talks about how companies accumulate valuable resources such as technology assets, intellectual property assets. But in reality the benefits of the company are not due to the ownership of resources alone, but how the capabilities of the company can be implemented effectively to integrate, coordinate, reconfigure the resources owned.

\subsection{Business Performance}

Performance can be interpreted as action (verb), not as an event (noun). Performance is an action that consists of several elements and not results in a moment only. Performance is seen as a process. Managing performance is a continuous process involving human resources to achieve the desired outcomes [23].

The company's performance as a successful new product, measured through new product development, and market development, measured growth growth through sales growth and market share, profitability, measured through operating profits, profit to sales ratio, cash flow operations, return on investment, return on assets, and product quality [24]. Moreover, it can also be argued that the performance of a company is essentially an achievement achieved by a business organization that can be seen from the results. In terms of business performance measurement not just enough use of single size [25, 26]. In Jaworski \& Kohli [26] and Chang [27] studies the company's performance is measured by overall business performance compared to last year and overall performance compared to its major competitors, while in Slater \& Narver [28] business performance is measured by profitability compared to target set.

Indicators of sales growth, employment growth, 
income growth and market share growth as the most important measurement of small enterprise performance [29].

Based on the review of literature that has been done then the measurements on the research variables can be arranged as follows:

Table 1 Variable Measurement

\begin{tabular}{|c|c|c|}
\hline Variables & Indicator & Source \\
\hline Synergy & Market access & Zineldin (2004); \\
\hline \multirow{4}{*}{ Cooperation } & Cost savings & Chris (2005) \\
\hline & Access & \\
\hline & information & \\
\hline & Sensitivity & \\
\hline Supplier & Trust & Morgan Hunt \\
\hline Network & Communication & (1994) ; Ganesan \\
\hline \multirow[t]{2}{*}{ Strategy } & Environmental & $(1994)$ \\
\hline & Dynamics & Ferdinand (2004) \\
\hline Business & Market & Bloom (2006) \\
\hline Development & penetration & \\
\hline \multirow[t]{6}{*}{ Strategy } & Market & \\
\hline & expansion & \\
\hline & Product & \\
\hline & development & \\
\hline & Product & \\
\hline & differentiation & \\
\hline \multirow{4}{*}{$\begin{array}{l}\text { Dynamic } \\
\text { Capabilities }\end{array}$} & Exploitation & Luo (2000) \\
\hline & capability & \\
\hline & Development & \\
\hline & Capability & \\
\hline \multirow{6}{*}{$\begin{array}{l}\text { Business } \\
\text { Performance }\end{array}$} & Sales turnover & Hadjimonalis \\
\hline & & \&Dickson,(2000) \\
\hline & Market share & \\
\hline & Profitability & \\
\hline & Popularity & \\
\hline & $\begin{array}{l}\text { Number of } \\
\text { customers }\end{array}$ & \\
\hline
\end{tabular}

\section{Concept Development}

\subsection{Synergy Cooperation and Dynamic Capabilities}

The synergy of cooperation has a sense of cooperation between two or more organizations through knowledge sharing and technology transfer activities and establishing mutually beneficial cooperation relationships. The synergy of cooperation includes the synergy in innovation determined by the current environmental conditions and the cooperating organization. Synergy in innovation will give companies the power to achieve higher income and lower risks that could harm the company [30].

Synergy in innovation achieved through intercompany cooperation will provide additional greater motivation to continue to develop innovations that can support the realization of the dynamic capabilities of a company [31, 32].

\subsection{Business Development Strategies and Dynamic Capabilities}

Business development strategies can be defined as a set of analysis tools, concepts, policies, arguments, and coherent actions that respond to higher challenges [33]. This will be able to map broadly how the company will compete. Strategy analysis will lead to the selection of specific business models, market segments, and more relevant approaches to the market and will be able to create and maintain distinct advantages with the market in general [34].

Given the unique advantages of the company resulting from the implementation of business strategy and development will create and improve the business model that can be maintained and guide the company's efforts to transform the organization so that it will be able to realize dynamic capabilities that lead to the achievement of better profit levels and can enable the company to maintain and enhance the capabilities and resources possessed in order to survive in the competition that occurred. Strategies in business combined with dynamic capabilities are able to dynamically implement, test and refine the development of new business strategies [35].

\subsection{Supplier Network Strategy and Dynamic Capabilities}

The supplier network leads to more dynamic changes due to changes in customer behavior. The company's supplier network strategy can provide a competitive advantage. A review of supplier network strategies and dynamic capabilities was undertaken by several researchers with the result that the theoretical structure of supply chain management practices as a recurring practice in an effort to create the firm's dynamic capabilities [36, 37, 38]. In the end, the relationship between supplier network strategy and dynamic capabilities will create competitive advantage of the company [39].

\subsection{Dynamic Capability and Business Performance}

Dynamic capability reflects the company's ability to achieve competitive advantage, meaning that dynamic capabilities have a very close relationship with company performance. Capability, according to Hitt et al. [40], represents a set of integrated resources used to carry out important activities. This 
capability integrates in the skills and knowledge of the workers in the company. Company competencies are based on capabilities, organizational routines, and the ability to learn. Therefore, the company must develop its core competencies continuously and or prepare for change and develop other new resources, to maintain competitiveness.

Teece \& Pisano [41] explains that the company's competitive advantage comes from dynamic capabilities embedded in high performance in a company, embedded in the company process, and conditioned by its developmental process. Meanwhile, new company growth is associated with dynamic capabilities and other important economic growth. The most probable capabilities and growths found are first-time $\mathrm{R} \& \mathrm{D}$ and inter-company alliances.

Performance dynamic capabilities will not simply affect performance improvements. This improvement will happen that there is only a conformity of the expected dynamics and the real dynamics, and only the ones that are actually has the required dynamic capabilities, hope is a performance outcome which is positive [42]. Dynamic capabilities also enable the company's business to be created, dispersed, and protected by intangible assets that support superior long-term corporate performance [43].

\section{Concept Framework}

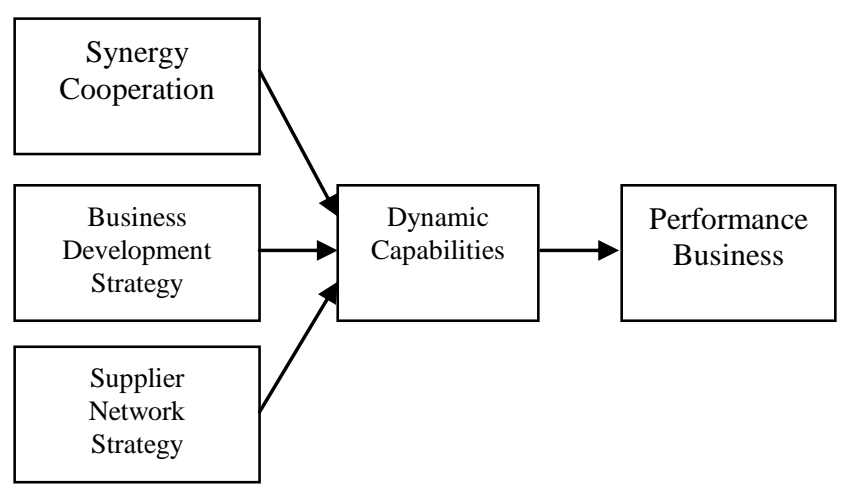

\section{References}

[1] Kurniawan, $\mathrm{R}$ and B. Christiananta. "Relationship Between Synergistic Cooperation and Dynamic Capability to The Business Performance A Literature Review from Resource Based View Perspective." GSTF Journal On Business Review (GBR), Vol. 3 No. 3, Juni 2016, p. 9-14.

[2] Hartini, Sri. "Peran Inovasi: Pengembangan Kualitas Produk dan Kinerja Bisnis." Jurnal Manajemen dan Kewirausahaan, Vol. 14 No. 1, 2016, p. 83-90.
[3] Pitoy, C. V., A. Tumbel dan M. Tielung. "Analisis Strategi Bersaing dalam Persaingan Usaha Bisnis Document Solution (Studi Kasus Pada PT. Astragraphia, Tbk Manado)." Jurnal Berkala Ilmiah Efisiensi, Vol. 16 No. 3, 2016, p. 302-312.

[4] Aaker, D. A. Strategic Market Management 5th edition, 1998. John Willey and Sons, Inc. USA.

[5] Eriksson, T. "Process, Antecedents and Outcome of Dynamic Capabilities.” Scandivanian Journal of Management SCAMAN-838, 2013, p.1-18.

[6] Shaheen, G. (1999, January 1). Convergence is upon us. Retrieved Desember 18, 2017, from allbusiness.com:

http://www.allbusiness.com/businessplanning/bu siness-development-strategicalliances/1664241.html

[7] Robbins, S. P. and M. Coulter. Management. 8th Edition. 2005. New Jersey, Prentice Hall.

[8] Barney, J. B. "Firm Resources and Sustained Competitive Advantage." Journal of Management, Vol 17, 1999, p.99-120.

[9] Bharadwaj, S., G. Varadarajan, P. Rajan, \& F. John, "Sustainable. Competitive Advantage in Service Industries: A Conceptual Model and. Research Proposition", Journal of Marketing, Vol. 57 No. 4, Oktober, 1993, pg. 83.

[10]Clulow, V., J. Gerstman, \& C. Barry. "The resource-based view and sustainable competitive advantage: The case of a financial services firm." Journal of European Industrial Training, Vol. 27(5), 2003, p. 220-232.

[11]Helfat, C. E., \& Peteraf, M. A. "The Dynamic Resource-Based View: Capability Lifecycles." Strategic Management Journal , 2003, p. 9971010.

[12]A. J. Palmer, D. Bejou, "Tourism destination marketing alliances", Annals of Tourism Research. 2000, Vol. 22 (3), pp. 616-629.

[13]Corning, A. P. "Synergy Another Idea Whose Time Has Come? ". Journal of Social and Evolutionary System, 1998, Vol 21, pp.1-9.

[14]S. Alan, D. Andreas, "Developing a decisionmaking framework for implementing purchasing synergy: a case study“. International Journal of Physical Distribution \& Logistics Management. Vol. 37. No.1, 2007, p. 64-89.

[15]Chris-Lucas. Value Metascience and Synergistic Choice. 2005. www.Chris-Lucas.com

[16]Chandra, Charu., and, Sameer Kumar. Supply chain management in theory and practice : a passing fad or a fundamental change, Industrial Managemnet \& Data Systems,. 2000. Vol. 100(3), p. 100-113. 
[17]Morgan, R. M., D. H Shelby D. Hunt. The commitment- trust theory of relationship marketing, Journal of Marketing. 2000. Vol. 58, July, p. 20-38.

[18]S. Ganesan, "Determinants of long-term orientation in buying- seller relationships ", Journal of Marketing. 1994. Vol. 58, April, p. 119.

[19]Bloom, N. Paul, L. N. Boone. Strategi Pemasaran Produk. 2006. Jakarta: Pustakaraya.

[20]Teece, D. J., G. Pisano, A. Shuen. "Dynamic Capabilities and Strategic Management." Strategic Management Journal, 1997. Vol. 18(7), p. 509-533.

[21]Eisenhardt, K. M and ,J. A. Martin. "Dynamic capabilities: what are they?." Strategic Management Journal, Oktober 2000, Vol. 21, p. 1105-1121.

[22]Luo, Y. "Dynamic capabilities in international expansion", Journal of World Business. 2004. 35 (4), pp. 355-378.

[23]Rue, L.L., dan Byars, L.L.. Management, Skill and Application, 1997. New York: Mc Graw Hill Companies.

[24]Pelhalm, A. M. "Market Orientation and Other Potential Influence on Performance in Small and Medium-Sized Manufacturing Firms.” Journal of Small Business Management, 2000. Vol. 38(1), p.48-67.

[25]Day, G. S. \& Wensley, R. "Assessing Advantage: Diagnosing Competitive Superiority." Journal of Marketing, 1998, Vol. 52(2): 1-20.

[26]Jaworski, B. J. and Kohli, A. K. "Market Orientation: Antecedent and Consequences." Journal of Marketing, 1993, Vol. 57(3), p.53-70.

[27]Chang, J. "The Decline in Value Relevance of Earnings and Book Values." Working paper, 1998. Philadelphia, PA.: University of Pennsylvania.

[28]Slater, S. F. \& Narver, J. C. "Intelligence Generation and Superior Customer Value." Journal of the Academy of Marketing Science, 2000. Vol. 28(1), p. 120-127.

[29]Hadjimonalis, A. and D. Keith, "Innovation Strategies of SMEs in Cyprus, A Small Developing Country", International Small Business Journal. 2000. 18, 4, pp. 62-79.

[30]Zhenqian, H. and X. Ming. "Research on the Dynamic Mechanism of Enterprise Synergy Innovation: A Literature Review." Asian Social Science, 2017, Vol. 13 No. 1, p. 141-150.

[31]Lawson, B., and D. Samson. "Developing Innovation Capability In Organisations: A
Dynamic Capability Approach.” International Journal of Innovation Management, Vol. 5 No. 3, September 2001 p. 377-400.

[32]Giniuniene, J and L. Jurksiene. "Dynamic Capabilities, Innovation and Organizational Learning: Interrelations and Impact on Firm Performance." Procedia - Social and Behavioral Sciences, Vol. 21 No. 3, 2015, p. 985 - 991.

[33]Rumelt, R.P. Towards a strategic theory of the firm. In: Lamb, R. (Ed.), Competitive Strategic Management, 1984. Prentice Hall, Englewood Cliffs, NJ.

[34]Casadesus-Masanell, R., and Ricart, J. E. "How to design a winning business model." Harv. Bus. Rev. Vol 89 Januari, 2017, p. 100-107.

[35]Teece, D. J. "Business Models and Dynamic Capabilities." Long Range Planning xxx, 2017, p. 1-10.

[36]Weick, K. E.. "What theory is not, theorizing is." Administrative Science Quarterly, Vol. 40 No. 3, 1995, p. 85-90.

[37]Defee, C.C. and Fugate, B.S. "Changing perspective of capabilities in the dynamic supply chain era." The International Journal of Logistics Management, Vol. 21, 2010), p. 180-206.

[38]Gold, S., Seuring, S. and Beske, P. "The constructs of sustainable supply chain management - a content analysis based on published case studies, Progress in Industrial Ecology." An International Journal, Vol. 7, p. 114-127.

[39]Maestika, I., and J. Cepinskis. "Dynamic Capabilities In Supply Chain Management." Procedia - Social and Behavioral Sciences, Vol. 21 No. 3, 2015, p. $830-835$.

[40]M. A. Hit, R. D. Ireland, R. E. Hoskisson. Manajemen Strategis, Daya Saing Globalisasi, Buku 1. 2001. Jakarta: Salemba Empat.

[41]Teece, D. J., and G. Pissano. "Dynamic capabilities of a firm: An introduction." Industrial and Corporate Change, Vol 3(3), 1994, p. 537-556.

[42]Ambrosini, V., Bowman, C. "What are dynamic capabilitiesand are they a useful construct in strategic management?/" International Journal of Management Reviews, Vol. 11, 2009, p. 29-49.

[43]Teece, D. J. "Explicating dynamic capabilities: The nature and microfoundation of (sustainable) enterprise performance." Strategic Management Journal, Vol 28(13), 2007., p. 1-10.

[44]Brodie, M. L. The B2B E-commerce Revolution: Convergence, Chaos and Holistic Computing. 2000. Bureau for e-Business Research - UBC Commerce Network. 
[45]M. Zineldin, T. Bredenlőw. "Performance measurement and management control-quality, productivity and strategi positioning: a case study of a Swedish bank." Managerial Auditing Journal. 2004, Vol 16 No. 9, pp. 484-499.

\section{Author Profile}

Roy Kurniawan currently is a Dr (cand.) in Postgraduate School of Universitas Katolik Widya Mandala Surabaya and lecturer at Ciputra University.
Budiman Christiananta, MA., Ph.D., Drs. Ec is a lecturer at Postgraduate School of Universitas Katolik Widya Mandala Surabaya.

Dr. Lenna Ellitan is a lecturer at Postgraduate School of Universitas Katolik Widya Mandala Surabaya. 